Article

\title{
Marine World Heritage and the Quest for Sustainability
}

\author{
Antonia Zervaki
}

Department of Political Science and Public Administration, University of Athens, Themistokleous 6, 10678 Athens, Greece; azervaki@pspa.uoa.gr; Tel.: +30-210-368-8963

Academic Editor: Kamrul Hossain

Received: 4 December 2015; Accepted: 15 February 2016; Published: 23 February 2016

\begin{abstract}
This paper discusses the contribution of marine sites of outstanding universal value, enlisted as natural and mixed sites in the World Heritage List, to the sustainability of marine resources and protection schemes. Departing from the strict application of the Convention's criteria, the management requirements and good practices will be discussed, with emphasis on the dissemination of the latter in other (non)protected areas as well as its contribution, in terms of the integrity principle to be met, to the expansion of this approach in areas beyond national jurisdiction through the development of synergies with existing and emerging marine environment protection regimes.
\end{abstract}

Keywords: marine environment; world heritage marine sites; natural and cultural heritage; sustainability; marine management

\section{Introduction}

Environmental protection emerged from the political discourse in the 60s. The organization of international conferences on the human environment in the decades that followed and the proliferation of international environmental instruments brought to the fore the urgent need for ensuring environmental sustainability, a concept that was incorporated systematically in the international agenda of the 80s and 90s. The adoption of the 1972 UNESCO World Heritage Convention signaled the turning point in environmental protection and conservation; the Convention promoted novel concepts since it was the first instrument that (a) adopted the 'heritage' approach in international environmental affairs, linking the interests of humanity with the environmental status of areas of exceptional value; (b) provided a comprehensive approach to conservation catering for both the cultural and the natural dimensions of the human environment; (c) served as a precursor to the ecosystem-based approach by establishing an inclusive management model; and (d) contributed to innovative international governance practices that incorporated governmental and non-governmental actors, the latter with enhanced institutional leverage, into the decision-making procedures. The conservation of the marine environment was incorporated in the Convention's scope of action since the outset of its implementation. Today, the outstanding universal value of 47 marine sites in 36 countries has been recognized, while there are also several mixed sites that encompass island, marine and coastal areas.

This paper will discuss the contribution of the World Heritage Convention, both at normative and operational levels, to the sustainability of marine sites of outstanding universal value. It will also examine the role and the prospects of the Convention's mechanisms in the conservation of marine resources within and beyond the administrative and physical boundaries of the marine areas enlisted in the World Heritage List. 


\section{Marine World Heritage: An Evolving Concept}

The UNESCO World Heritage Convention was adopted in 1972 by the organization's General Conference having as a primary objective to identify and preserve cultural and natural sites of universal value. Marine sites, although not included in the definition of natural heritage provided by the treaty itself $^{1}[1]$, were incorporated in the Convention's scope of action at the outset of its implementation, through the Operational Guidelines issued by the World Heritage Intergovernmental Committee (hereafter WH Committee) ([2], para. 10) ${ }^{2}$. State practice also confirmed this orientation since Ecuador inscribed the first marine site, the Galápagos Islands, in the World Heritage List in 1978. In the decades that followed, the outstanding universal value of 47 marine sites in 36 countries has been recognized [3] based on their exceptional natural features, while there are also several mixed sites that encompass island, marine and coastal areas [3].

The concept of outstanding universal value is not defined in the Convention, but in the Operational Guidelines of the WH Committee. According to the latest version of the Guidelines, outstanding universal value means "cultural and/or natural significance which is so exceptional as to transcend national boundaries and to be of common importance for present and future generations of all humanity. As such, the permanent protection of this heritage is of the highest importance to the international community as a whole" ([4], para. 49). The attribution of outstanding universal value to marine sites depends mainly on the fulfillment of one of the specialized natural criteria also decided upon by the Committee, while, in the case of some marine properties inscribed as mixed, sites in the World Heritage of the cultural criteria may apply as well (see Table 1$)^{3}$.

Another criterion to be considered in the nomination process, horizontal in character, is that of the integrity of marine sites. According to the Guidelines ([4], para. 88), integrity constitutes "a measure of the wholeness and intactness of the natural and/or cultural heritage and its attributes. Examining the conditions of integrity, therefore requires assessing the extent to which the property: (a) includes all elements necessary to express its Outstanding Universal Value; $(b)$ is of adequate size to ensure the complete representation of the features and processes which convey the property's significance; (c) suffers from adverse effects of development and/or neglect" ([4], para. 88). Thus, integrity for marine sites is assessed once again by the exceptional character and the superlative value of the sites' features combined with spatial criteria, the scale of the protected area that will allow the effective protection of the property.

1 Article 2 defines natural heritage as "(1) natural features consisting of physical and biological formations or groups of such formations, which are of outstanding universal value from the aesthetic or scientific point of view; (2) geological and physiographical formations and precisely delineated areas which constitute the habitat of threatened species of animals and plants of outstanding universal value from the point of view of science or conservation; (3) natural sites or precisely delineated areas of outstanding universal value from the point of view of science, conservation or natural beauty."

2 According to the first Operational Guidelines adopted in 1977, outstanding universal value will be recognized in sites fulfilling four criteria, one of them (criterion (ii)) making explicit reference to the marine environment, according to which nominated properties should "be outstanding examples representing significant ongoing geological processes, biological evolution and man's interaction with its natural environment. As distinct from the periods of the earth's development [mentioned in criterion (i)], this focuses upon ongoing processes in the development of plants and animals, landforms and marine and freshwater bodies. This category would include for example (a) as geological processes, glaciation and volcanism; (b) as biological evolution, examples of biomes such as tropical rainforests, deserts and tundra; (c) as interaction between man and his natural environment, terraced agricultural landscapes."

3 As of October 2015, only four out of forty-seven marine properties of the World Heritage List are inscribed as mixed sites: the volcanic archipelago of St Kilda in the United Kingdom (1986) according to criteria (iii), (v), (vii), (ix) and (x); Ibiza, Biodiversity and Culture in Spain (1999) according to criteria (ii), (iii), (iv), (ix) and (x); the Papahānaumokuākea in the Hawaiian archipelago in USA inscribed in 2010 according to criteria (iii), (vi), (viii), (ix) and (x); and the Rock Islands Southern Lagoon in Palau (2012) according to criteria (iii), (v), (vii), (ix) and (x). See [3]. 
Table 1. World Heritage criteria.

\begin{tabular}{|c|c|c|}
\hline & Cultural & Natural \\
\hline $\begin{array}{l}\text { (i) } \\
\text { (ii) }\end{array}$ & $\begin{array}{l}\text { represent a masterpiece of human creative genius; (vii) } \\
\text { exhibit an important interchange of human values, } \\
\text { over a span of time or within a cultural area of the (viii) } \\
\text { world, on developments in architecture or technology, } \\
\text { monumental arts, town-planning or } \\
\text { landscape design; } \\
\text { bear a unique or at least exceptional testimony to a } \\
\text { cultural tradition or to a civilization which is living or (ix) } \\
\text { which has disappeared; } \\
\text { be an outstanding example of a type of building, } \\
\text { architectural or technological ensemble or landscape } \\
\text { which illustrates (a) significant stage(s) in } \\
\text { human history; } \\
\text { be an outstanding example of a traditional human } \\
\text { settlement, land-use, or sea-use which is } \\
\text { representative of a culture (or cultures), or human } \\
\text { interaction with the environment especially when it } \\
\text { has become vulnerable under the impact of } \\
\text { irreversible change; } \\
\text { be directly or tangibly associated with events or } \\
\text { living traditions, with ideas, or with beliefs, with } \\
\text { artistic and literary works of outstanding universal } \\
\text { significance. (The Committee considers that this } \\
\text { criterion should preferably be used in conjunction } \\
\text { with other criteria); }\end{array}$ & $\begin{array}{l}\text { contain superlative natural phenomena or areas of } \\
\text { exceptional natural beauty and aesthetic importance; } \\
\text { be outstanding examples representing major stages of } \\
\text { earth's history, including the record of life, significant } \\
\text { on-going geological processes in the development of } \\
\text { landforms, or significant geomorphic or } \\
\text { physiographic features; } \\
\text { be outstanding examples representing significant } \\
\text { on-going ecological and biological processes in the } \\
\text { evolution and development of terrestrial, fresh water, } \\
\text { coastal and marine ecosystems and communities of } \\
\text { plants and animals; } \\
\text { contain the most important and significant natural } \\
\text { habitats for in-situ conservation of biological } \\
\text { diversity, including those containing threatened } \\
\text { species of Outstanding Universal Value from the } \\
\text { point of view of science or conservation. }\end{array}$ \\
\hline
\end{tabular}

Integrity, however, although in principle interpreted as synonymous to large scale areas' nominations, brings to the fore significant challenges due to the fragmented jurisdiction over the marine space combined with the geographical realities of spatial distribution of jurisdiction of adjacent or opposite coastal states in enclosed or semi-enclosed seas and the significant administrative and financial burden for competent authorities in the case of large marine areas conservation; thus, contemporary practice vis à vis the integrity principle is oriented towards alternative solutions, the

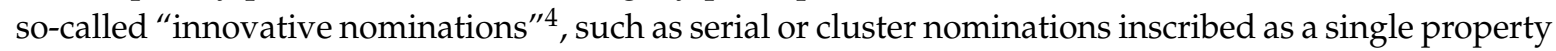
in the World Heritage List ${ }^{5}$, or transboundary nominations (that may include serial nominations as well) in order to ensure integrated ecosystem protection in cases of jurisdictional fragmentation. There are also several suggestions for improving the efficiency of smaller scale nominations in the context of "non-contiguous" locations with the provision of transport corridors to improve connectivity and ensure the integrity of ecological and biological processes (e.g., in the case of species migration) affecting the universal value of a marine property; however, research in the domain of connectivity in the marine environment is still in the early stages ([6], pp. 19, 27).

Last but not least, integrity is connected to the impact of development, the latter being related to human activities either being land-based (e.g., coastal communities' waste and sewage, pesticides and fertilizers, etc.) or conducted at sea (e.g., ship or offshore oil exploitation accidents, dumping of sea water ballast from tankers carrying crude oil, etc.). In these cases, the nomination of mixed sites, with island or coastal components, enhances the safeguard of the marine areas' integrity, while the

4 A term used by the experts participating in the workshop on the World Heritage Marine Biodiversity in 2002 ([5], pp. 6, 17). The World Heritage Marine Biodiversity Workshop: Filling Critical Gaps and Promoting Multi-Site Approaches to New Nominations of Tropical Coastal, Marine and Small Island Ecosystems" was held in Hanoi, Vietnam from 25 February to 1 March 2002 on the occasion of the 30th anniversary of the World Heritage Convention.

5 According to the definition provided in the Hanoi Workshop, a serial nomination "consists of two or more physically unconnected areas, but which are related for example because they belong to the same geological, geomorphological formation, the same biogeographic province or the same ecosystem type. The series itself should be of outstanding universal value, not necessarily its components taken individually. Serial nominations are inscribed as a single property on the World Heritage List." ([5], p. 12). 
efforts to develop synergies with other specialized instruments in the domain of environmental protection (such as the Biodiversity Convention) is also an option.

\section{The World Heritage Regime and Its Impact on Marine Sustainability}

The concept of sustainability is inextricably linked with sustainable development literature and practice founded on the definition provided in the Brundtland Report: "Sustainable development is development that meets the needs of the present without compromising the ability of future generations to meet their own needs. It contains within it two key concepts:

- the concept of needs, in particular the essential needs of the world's poor, to which overriding priority should be given; and

- the idea of limitations imposed by the state of technology and social organization on the environment's ability to meet present and future needs." ([7], p. 47)

Sustainable development has become an "ideal political concept" ([8], p. 111), incorporated in the political and academic debate on development in the 1990s; it was present in the jargon of different actors that represented different interests and ideological perceptions, ranging from international and governmental institutions to activists, triggering several interpretations (see $[9,10])$ that attempted to shed light in the different components or conceptual pillars of sustainable development: economic growth, social equity and environmental protection ([11], p. 151).

Gradually, the discussion focused on the objective of sustainability, the ability to maintain the natural capital, social standards and economic growth ([12], p. 379): the emphasis here is on the functional or operational dimensions of the political concept of sustainable development. Hence, sustainability is related to the development of institutions, policy and management tools required in order to accomplish the sustainable development objective ${ }^{6}$, or even with more specialized dimensions such as monitoring and assessment processes and the development of sustainability indicators and indices [13].

In order to examine the impact of the World Heritage Convention on the sustainability of the marine ecosystems, the following parameters will be examined: (a) the contribution of the Convention's regime in the identification and conservation of the environmental qualities of the nominated marine sites-this process involves the construction of a uniform methodology, common for every marine site of exceptional value around the globe, based on the natural criteria applied for the inscription and the maintenance of a site on the World Heritage List; (b) the economic dimensions of the nomination process, in relation to the objective of economic sustainability of local societies but also of the conservation schemes; (c) the social-institutional aspects of marine World Heritage sites based on the concept of intra- and intergenerational rights; and (d) the cultural component of sustainability, which is brought to the fore by the Convention itself since it provides for a comprehensive framework of the protection of cultural and natural heritage. Thus, for the purposes of this paper, marine World Heritage sustainability analysis encompasses the environmental, economic, social-institutional and cultural dimensions.

\subsection{The Environmental Dimension ${ }^{7}$}

The Convention clearly aims at the conservation of the natural elements (both renewable and non-renewable) of the most significant marine sites in the world. Marine conservation as provided for in the World Heritage regimes requires the preservation of a wide range of natural attributes that grant

6 In this context, the "prism of sustainable development" perception was introduced. The latter expands the conventional sustainability triangle based on the three-pillar scheme of environmental, social and economic dimensions of sustainability by adding the institutional dimension, as presented in ([12], pp. 380, 382). 
universal value to the nominated marine sites. These attributes, as already mentioned, are defined by the natural World Heritage criteria, namely,

Criterion vii connects outstanding universal value to the existence of superlative natural phenomena to areas of exceptional natural beauty and aesthetic importance or both. According to UNESCO's Resource Manual ([15], p. 40), the attribute of superlative natural phenomena can be "objectively measured and assessed". Extensive linear reef complexes, such as the Great Barrier Reef in Australia ${ }^{8}$, the Belize Barrier Reef Reserve System ${ }^{9}$, or the existence of steep walls and cavings, as in the case of the Malpelo Fauna and Flora Sanctuary in Colombia ${ }^{10}$, constitute illustrative examples. Another feature falling into this category is the aggregation of living resources (e.g., sharks, mammals or turtles). On the other hand, exceptional natural beauty and aesthetic importance is based on qualitative criteria, often lacking the objective character of quantified assessment ([1], p. 73; [15], p. 40; [16], p. 10). Although the appreciation of the scenic quality of a marine area does involve a degree of subjectivity, since it is not founded on measurable data, it can hardly be doubted in the cases of World Heritage nominations. First of all, there is no marine nomination based solely on criterion vii (in line with IUCN's recommendations on the application of criterion vii in conjunction with other criteria) ${ }^{11}$. Secondly, reference to marine aesthetic values is linked to the existence of exceptional natural or biological phenomena, such as coral reefs, island agglomerations or icescapes ([6], p. 25), and thus indirectly connected to measurable attributes. What is important though is that reference to natural beauty contributes to a broader understanding of the natural environment and the construction of environmental values of a "non-service" character. According to the International Law Commission, "[e]nvironment could be defined in a restricted way, limiting it exclusively to natural resources, such as air, soil, water, fauna and flora, and their interaction. A broader definition could embrace environmental values also. The Commission has opted to include in the definition the latter encompassing non-service values such as aesthetic aspects of the landscape also. This includes the enjoyment of nature because of its natural beauty and its recreational attributes and opportunities associated with it" ([18], p. 133). Apart from the broad conceptual perception of the environmental qualities, the Convention system has adopted a comprehensive approach vis $a$ vis the interpretation of the integrity condition in conjunction with the natural beauty criterion. The WH Committee clarified that the proposed properties for their scenic beauty should incorporate the broader area "linked to the maintenance of the aesthetic qualities" ([4], para. 92). Thus, host states should expand their protection schemes in order to ensure that the ecological processes that support the scenic qualities of a property are sustained.

Criterion viii applied on the marine environment is interpreted as outstanding examples ([6], pp. 10-16) of (a) marine geology, including plates and tectonic features,

7 Based on the perception of environmental sustainability within the context of ecological economics provided by Daly [14], an advocate of the precautionary approach in relation to the use of natural resources. Daly has proposed three basic principles relating to yield sustainability in terms of renewable resources, to the bearing capacity of the environment in relation to waste disposal, whether regular or accidental, and to the balanced replacement of non-renewable stocks depleted with alternative renewable resources.

8 Inscribed in the World Heritage List in 1981 under the criteria (vii), (viii), (ix) and (x), the Great Barrier Reef is “the world's most extensive coral reef ecosystem ... covering an area of 348,000 square kilometers and extending across a contiguous latitudinal range of $14^{\circ}\left(10^{\circ} \mathrm{S} \text { to } 24^{\circ} \mathrm{S}\right)^{\prime \prime}[3]$.

9 Inscribed in the World Heritage List in 1996 under the criteria (vii), (ix) and (x), the Belize Barrier Reserve System constitutes the largest reef complex in the Atlantic-Caribbean region and the second largest reef system in the world [3].

10 Inscribed in the World Heritage List in 2006 under the criteria (vii) and (ix) [3].

11 Criterion vii was present in almost in all nominations until 1995 (with the Sundarbans National Park, Banc d'Arguin National Park and the Whale Sanctuary of El Vizcaino being the only exceptions), but its use has been significantly limited during the last two decades ([17], p. 64). 
hotspots and seamounts, sedimentary processes, and hydrogeological features (such as vents or seeps); and (b) oceanography, including ocean currents, water masses and stratification. In terms of the chemical composition of marine water, there is a basic division of marine areas in terms of the proximity to the coast and a vertical classification of ocean space relating to the ability to absorb light depending on the depth, waves and other fluid phenomena such as tides, coastal and land-sea interactions, and marine ice processes and features. Thus, applying criterion viii to marine World Heritage nominations includes outstanding examples representing major stages of the earth's history (such as the case of the Galápagos islands in Ecuador that constitute demonstration of "the evolution of the younger volcanic areas in the west and the older islands in the east" $)^{12}$, including the record of life (as in the Great Barrier Reef, an "ecosystem that has evolved over millennia" [3]), significant on-going geological processes in the development of landforms, or significant geomorphic or physiographic features (such as the Heard and MacDonald Island ${ }^{13}$ or the Papahānaumokuākea in the United States ${ }^{14}$, which represent an island hotspot progression). In order to meet the integrity condition, States' nominations under this criterion should incorporate "all or most of the key interrelated and interdependent elements in [the] natural relationships" ([4], para. 93), ensuring the sustainability of the above mentioned on-going or historical processes.

Criterion ix is the only criterion that explicitly mentions marine systems. The wording of this criterion was often combined or even confused with criterion (x). According to IUCN "criterion ix relates to ecosystems, communities and the ecological and biological processes that shape and sustain them, while criterion $x$ relates to species and the habitats or sites most important for their conservation" ([6], p. 17). It encompasses ([6], pp. 18-21) productivity and biochemical cycles (e.g., the Islands and Protected Areas of the Gulf of California, which constitute a unique habitat consisting of 'bridge' and oceanic islands, and which combined with the oceanographic conditions and processes to enhance marine productivity and biodiversity conservation in the area ${ }^{15}$; connectivity of marine areas (in relation to species migration) (the transboundary nomination of Kluane/Wrangell-St. Elias/Glacier Bay/Tatshenshini-Alsek situated in Alaska and North Western Canada, which assists the spawning of anadromous fish, linking marine and land conservation) ${ }^{16}$; and marine ecosystem patterns, processes and services (the case of the Heard and MacDonald Island is illustrative due to the intact ecosystem from the point of view of alien species and human impact [3]). In the case of the implementation of the integrity criterion in properties proposed for nomination under criterion ix, host States should ensure that the size of the site is sufficient to preserve the ecosystem and biodiversity features they support. In the case of marine sites, the WH Committee provides the example of coral reef areas that "should include [... ] seagrass, mangrove or other adjacent ecosystems that regulate nutrient and sediment inputs into the reef" ([4], para. 94).

Criterion $x$ provides for conservation of marine biological diversity in situ, focusing on species that are threatened, through the protection of their habitats. In this case, the integrity criterion links once again the spatial dimension of marine conservation with

12 Inscribed in the World Heritage List in 2001 under the criteria (vii), (viii), (ix) and (x) [3].

13 Inscribed in the World Heritage List in 1997 under the criteria (viii) and (ix) by Australia, these sub-Antarctic volcanic islands constitute an example of continuing geological processes that "provide an understanding of the role of crustal plates in the formation of ocean basins and continents, and of atmospheric and oceanic warming" [3].

14 Inscribed in the World Heritage List in 2010 under the criteria (iii), (vi), (viii), (ix) and (x) [3].

15 Inscribed in the World Heritage List in 2005 (with minor modifications in 2007 and 2011) by Mexico under the criteria (vii), (ix) and (x) [3].

16 Inscribed in the World Heritage List in 1979 under the criteria (vii), (viii), (ix) and (x) [3]. 
biodiversity; the WH Committee provides the following examples to be applied in marine sites: " . . an island ecosystem should include habitats for maintaining endemic biota; a property containing wide ranging species should be large enough to include the most critical habitats essential to ensure the survival of viable populations of those species; for an area containing migratory species, seasonal breeding and nesting sites, and migratory routes, wherever they are located, should be adequately protected" ([4], para. 95). The case of the bird communities in the Gough and Inaccessible Islands in the South Atlantic Ocean ${ }^{17}$ or in the Banc d'Arguin National Park ${ }^{18}$ constitute illustrative examples of World Heritage Convention's marine sites contribution to biodiversity sustainability.

\subsection{The Economic Dimension}

Economic sustainability in the case of marine World Heritage is pursued under the broader objective of "balancing economic development with conservation" ([19], p. 14). The Operational Guidelines focus mainly on the preservation of the outstanding universal value of (marine) World Heritage properties, considering sustainable development as part of the management requirements ([4], para. 132). There has been a shift of focus during the last five years: The Convention's system strategic orientation, as depicted in the 2011 Strategic Action Plan for 2012-2022 [20] ${ }^{19}$, attempts to "mainstream a sustainable development perspective" in the processes foreseen by the World Heritage regime ([21], p. 16) through the development of a relevant policy (that is expected be integrated in the Operational Guidelines) ([22], para. 5). Thus, the incorporation of economic sustainability prerogatives in the case of marine sites conservation encompasses the following dimensions [23]:

Regional development: Since few marine sites stand isolated from the coastal or island communities, marine heritage is connected to their socio-economic needs and aspirations; in this context, the generation of income from activities related to marine nominations is not excluded from the management approach of the Convention's system. Apart from the traditional economic activities related to the sea (such as fisheries ${ }^{20}$, maritime transport ${ }^{21}$, etc.), the recognition of the universal value per se constitutes an economic asset and may contribute to the development of sustainable economic

17 Inscribed in the World Heritage List in 1995 (extended in 2004) be Great Britain under the criteria (vii) and (x) [3].

18 Inscribed in the World Heritage List in 1989 by Mauritania under the criteria (ix) and (x) [3].

19 Sustainable development constitutes a priority of World Heritage Goal 3: Heritage protection and conservation considers present and future environmental, societal and economic needs ([20], p. 13).

20 In some World Heritage properties fishing is prohibited. This is the case with Tubbabataha Reefs in Philippines, a marine site inscribed in World Heritage List in 1993 (extended in 2009) under the criteria (vii), (ix) and (x) [3]. Economic activity is restricted to tourism and recreation; it is estimated, however, that protection measures regarding fisheries in this area have increased fishing capacities in marine areas nearby ([23], p. 38). In some other areas, regulated fisheries is provided for local populations promoting sustainability of fishing stocks and subsequently the income generated by catches. A project implemented in the Sian Ka' an World Heritage site in Mexico, enlisted in 1987 under the criteria (vii) and (x) [3], assisted local fishermen to change their fishing techniques and gradually abandon the use of nets by taking advantage of existing scientific knowledge, biodiversity mapping of the area and systematic recording of their catches. The change of fishing attitudes resulted in a 30\% increase of local income generated from lobster catches ([19], p. 74).

21 The profession of boat operator that transfer visitors to the marine properties' is very popular in World Heritage marine sites, especially where other economic activities, as fisheries in the case of the Tubbabataha Reefs site mentioned above ([23], p. 38), are excluded. The case of the Green Fjords initiative in the West Norwegian Fjords-Geirangerfjord and Nærøyfjord in Norway, a site inscribed on the World Heritage List in 2005 under the criteria (vii) and (viii) [3], constitutes an alternative model for maritime transport operations within World Heritage sites. Site managers have developed a partnership with the private sector of boat operators ensuring that only the boats that would leave no "footprint" on the site's environment would have access in the area ([19], p. 84). 
activities including mainly "blue" tourism ${ }^{22}$ but also local products and services branding ${ }^{23}$, etc., while management and restoration activities may contribute to new employment opportunities ${ }^{24}$.

Contribution to ecosystem services sustainability at local and global levels: In this case, local and global communities may benefit indirectly from non-market services provided by marine World Heritage conservation, such as protection from floods in the case of mangrove forests or coral reefs ${ }^{25}$ and carbon sequestration $^{26}$. In this case, the Convention contributes to preventing disasters or conditions that would be very expensive or difficult to reverse.

Financial sustainability of the conservation project: The allocation of resources required for the full cycle of conservation management plans constitutes a significant challenge for the contracting parties, taking into account the requirements and high standards set by the Convention and the Operational Guidelines; the fact that most of the protected areas are located in developing countries; and the impact of human activities and accidents taking place beyond the administrative boundaries of the protected sites or of natural phenomena mainly due to climate change. World Heritage nominations and properties, however, may have access to different sources of funding. First of all, they are all eligible for the international financial assistance provided by the Convention. The World Heritage Fund [26,27] supports projects related to emergency assistance ${ }^{27}$, conservation and management assistance (incorporating assistance for training and research, technical co-operation and promotion and education) ${ }^{28}$ and preparatory assistance (preparation of nomination files and tentative lists including national and cross-border nominations $)^{29}$ ([4], para. 235). Priority is given to sites inscribed in the List of World Heritage in Danger. However, the annual budget of the Fund is limited to $\$ 4$ million, and the demands for international assistance have significantly increased; thus, international assistance cannot sustain long-term and/or large-scale projects. In order to address the financial demands of marine World Heritage conservation, competent authorities usually turn to complementary or alternative sources of funding. International financial institutions and programs, mainly through the Global Environmental Fund ${ }^{30}$ may fund relevant projects, while the European Union supports

22 Tourism constitutes the economic activity that has been mostly studied in the case of World Heritage sites. Several studies have been conducted focusing on different dimensions of tourism for the Belize Barrier Reef Reserve System, the Great Barrier Reef, the Peninsula Valdes, the Galapagos islands ([23], pp. 32-33), while EU has sponsored a project in the Wadden Sea area for the elaboration of a regional sustainable tourism strategy and enhance socio-economic development [24] in the Dutch-German-Danish Wadden Sea region, inscribed as a transboundary property in the World Heritage List in 2009 (extended in 2014) under the criteria (viii), (ix) and (x) [3].

23 In the case of the Sian Ka'an World Heritage site, artisanal spiny lobster fisheries have been awarded the Marine Stewardship Council certification, creating opportunities for access in the international markets as eco-labeled products ([19], p. 74). A broader strategy has been adopted in the Wadden Sea area (see above) in relation to the comprehensive branding and marketing of the area's outstanding universal values ([19], p. 89).

24 In the case of the Lagoons of New Celedonia, inscribed by France in 2008 under the criteria (vii), (ix) and (x) [3], employment related to ecosystem services of the properties' conservation scheme include 350 professionals in the domain of artisanal fisheries and 1600 professionals in the domain of blue tourism services ([23], p. 40).

25 It is estimated that the annual cost of damages from coastal floods in New Caledonia would raise to $7 \mathrm{~m}$ euros if not prevented by the coral reef and associated ecosystems ([23], p. 39), based on the study of N. Pascal [25]).

26 The role of posidonia meadows in absorbing atmospheric CO2 emissions is significant. The example of the Ibiza, Biodiversity and Culture World Heritage property is illustrative ([23], p. 22).

27 Mexico received $\$ 62,000$ in 2007 for the recuperation of supervision infrastructure lost after hurricane Dean in Sian Ka'an Biosphere Reserve [28].

28 Philippines have repeatedly received international assistance for conservation measures of the Tubbataha Reef Marine Park after its designation as a World Heritage site: In 1996 it received \$20,000 as technical assistance for the protection and public awareness for its conservation; in 2003, \$20,000 for the conduct of an impact analysis of illegal fishing activities on the conservation of the site; in 2006, the National Forum on the conservation of the Tubbataha Reef Marine Park and the Greater Sulu Sea was funded with $\$ 29,816$; in 2010 it received $\$ 29,996$ for improving conservation and management in the Tubbataha Reefs; and in 2012 \$22,262 for the Strengthening Conservation Management Policies [28].

29 Belize has received financial assistance of $\$ 9700$ from the World Heritage Fund for the preparation of its tentative list for natural heritage (including marine heritage) in 1993 [28]. Philippines have also received preparatory assistance (\$10,500) for the systematic review of protected area system to prepare a list of potential World Heritage sites and nomination dossiers in 1989 (including marine sites) and an extra $\$ 18,488$ for the preparation of a World Heritage extension nomination for Tubbataha Reef Marine Park in the Philippines in 2007 [28].

30 It is estimated that $70 \%$ of the external funding raised for World Heritage sites is supplied through the Global Environmental Facility ([29], p. 2). 
a number of actions through its financial mechanisms ${ }^{31}$. Another significant source of financial resources is donations from the private sector ${ }^{32}$. The existence of national ${ }^{33}$ or regional ${ }^{34}$ World Heritage Foundations in line with article 17 of the Convention ${ }^{35}$, which operate at the international level, have also mobilized financial resources for the protection of World Heritage properties mainly in the developing world. Last but not least, revenues from ecosystem services may cover part of the management $\cos ^{36}$, although national subsistence constitutes the most secure financial source.

\subsection{The Social-Institutional Dimension}

The World Heritage Convention has introduced several conceptual and institutional novelties. First of all, the definition of a natural resource as heritage ${ }^{37}$, transcends the traditional intergovernmental logic of international environmental agreements where contracting parties constitute the subjects of the environmental legislation by bringing to the fore another agent: mankind and its rights $[31,32]^{38}$. In addition, humanity is a recipient of certain rights related to marine resources that fall under the jurisdiction of states, in contrast with the conceptualization of humanity's rights in the context of the law of the sea $[37,38]$. In the case of marine World Heritage sites, one may discern two dimensions when referring to these rights:

(a) the synchronic dimension: Marine heritage is conceived as a vital resource for the members of the present generation. First of all, the 1972 UNESCO Convention's mechanism aims at a more representative marine sites inventory ([6], p. 1; [39]) in terms of regional ecosystems representation. Intragenerational equity, however, is not interpreted solely as the balanced representation of marine sites inscribed in the World Heritage List, but also as equal rights over a healthy marine environment (and its implications for living conditions as well as development prospects) locally as well as globally.

(b) the diachronic dimension: Article 4 of the 1972 Convention recognizes "the duty of ensuring the identification, conservation, presentation and transmission to future generations of the [world] cultural and natural heritage situated on their territory", linking World Heritage protection with the concept of intergenerational equity and different generations' rights over the marine resources. In order to meet this primordial obligation to preserve the qualitative characteristics of human environment in order not to impair the quantity or quality of the natural assets to be enjoyed or used by future generations ([40]; [41], pp. 398-99) states should develop their legislation in order to implement this "duty to ensure the transmission of heritage" ([42], p. 115).

31 The project on sustainable tourism in the Wadden Sea region (see above) funded by the European Regional Fund and the Interreg IVB North Sea Region Programme constitute an illustrative example.

32 Private companies have co-funded several marine World Heritage projects such as the project to conserve freshwater, marine and coastal resources in and around Sian Ka'an in Mexico.

33 Such as the German World Heritage Foundation or the NESCO/Netherlands Funds-in-Trust.

34 Such as the Nordic World Heritage Foundation or the African World Heritage Fund.

35 "The States Parties to this Convention shall consider or encourage the establishment of public and private foundations or associations whose purpose is to invite donations for the protection of the cultural and natural heritage as defined in Articles 1 and 2 of the Convention".

36 In 2006 revenues from entrance fees in Tubbataha Reefs covered $80 \%$ of the core management budget ([23], p. 39).

37 The concept of 'heritage' was also used in the 1972 Stockholm Declaration in a more limited scope. According to Principle 4 "Man has a special responsibility to safeguard and wisely manage the heritage of wildlife and its habitat ... " ([1], p. 64; [30]).

38 It should be mentioned that, in the case of natural heritage, international criminal responsibility is at present excluded for environmental damage [33] in contrast to the cultural heritage domain where acts against cultural heritage were brought before international criminal courts [34]. The example of the shelling attack on the Old City of Dubrovnik, a World Heritage site, during the civil war in the former Yugoslavia is illustrative: The act was characterized as "an attack not only against the history and heritage of the region, but also against the cultural heritage of humankind" by the International Criminal Court for the Former Yugoslavia ([35], para. 51). A more recent example is the opening of a case before the International Criminal Court in September 2015 against Ahmad Al Faqi Al Mahdi for the destruction of cultural heritage in Mali [36]. 
The issue of intra- and intergenerational rights brings to the fore the relation of marine heritage conservation to human development. The concept of human development encompasses the monetized dimensions of marine sites' preservation and the process of economic development, including economic growth and revenue generation, as well as the so-called "non-monetized" benefits, such as the preservation of the local natural capital and marine bio-diversity. Additionally, preserving marine environmental assets ensures environmental sustainability, through the mild exploitation of the natural environment that forms part of a protected marine site or of its surroundings, contributing to long-term social benefits. The contribution of "traditional ownership and cultural traditions of coastal and small island" to "long-term conservation" [43] as recognized by the participants of the Hanoi Workshop on World Heritage Marine Biodiversity [5], constitutes an illustrative example of the contribution of social patterns to marine sustainability.

From an institutional point of view, the Convention has established a multilevel system of protection characterized as being close to a "transnational public trusteeship" ([44], pp. 59-60) $)^{39}$ unfolding in several levels and entangling different actors. The main dimensions encompass:

(a) regulation and management at the national level: States have to develop appropriate legislation and administrative structures as well as comprehensive management programs; the nomination process is a laborious venture since nomination files are examined not only on the basis of their exceptional value according to the criteria analyzed above but also in terms of the legislative measures and the quality of the management plans applied in the area as well as the ability of the competent authorities and the local communities to implement them. Once inscribed in the World Heritage List, marine sites are regularly assessed in order to ensure that the outstanding universal value and the integrity of the sites at the time of inscription "are sustained or enhanced" ([4], para. 96). The assessment is realized through the reactive ${ }^{40}$ and the periodic ${ }^{41}$ reporting systems including in situ assessments realized by experts ${ }^{42}$ and competent authorities may take additional or corrective measures where needed ${ }^{43}$.

(b) depolitization of the decision-making processes due to the enhanced role of independent experts, both in the nomination and the monitoring processes. In the case of marine properties, IUCN is the advisory body that assists the World Heritage Committee ([49],

39 The public trusteeship concept has also been envisaged in the case of the Barcelona Convention system for the protection of the Mediterranean See [45].

40 Reactive monitoring derives from states parties' obligations assumed according to article 4 of the Convention (see above) and constitutes a process initiated by the WH Committee when "exceptional circumstances occur or work is undertaken which may have an impact on the Outstanding Universal Value of the property or its state of conservation" ([4], para. 169). Reactive monitoring is foreseen in cases where a World Heritage property is or is intended to be inscribed in the List of World Heritage in Danger (as in the case of the Belize Barrier Reef System [46]), or in the procedures that may result in the deletion of a site from the World Heritage List.

41 In line with article 29 of the Convention "states parties are requested to submit reports to the UNESCO General Conference through the World Heritage Committee on the legislative and administrative provisions they have adopted and other actions which they have taken for the application of the Convention, including the state of conservation of the World Heritage properties located on their territories" ([4], para. 199). Periodic reporting system is organized on a regional basis, since states of the same geographical region have to submit their periodic report every six years. In this way the Convention's monitoring processes unfold both at the national and at the regional levels. This approach also facilitates the assessment of transboundary sites as in the case of The Wadden Sea or the Kluane/Wrangell-St. Elias/Glacier Bay/Tatshenshini-Alsek World Heritage properties mentioned above.

42 In situ assessment comprises the reactive monitoring missions at the request of the WH Committee and the advisory missions at the invitation of the states parties of the Convention ([4], paras. 31d and 184).

43 As in the case of the Belize Barrier Reef Reserve System inscribed in the List of World Heritage in Danger in 2009 after a joint World Heritage Centre/IUCN Reactive Monitoring mission in Belize, the latter was asked by the World Heritage Committee to implement a series of corrective measures [46]. After another IUCN Monitoring mission in 2013, Belize submitted a State of Conservation Report [47] to be followed by a joint World Heritage Centre/IUCN technical mission in early 2015 that agreed with the state party on "the development of a desired state of conservation for the removal of the property from the List of World Heritage in Danger" based on specific indicators, methods of verification and timeframe [48]. 
p. 188) while ICOMOS provides its expertise for the marine mixed sites inscribed on the List. Although IUCN and ICOMOS' contribution is purely advisory, in line with article 8 of the Convention, in practice, their opinion is decisive due to the complex methodology required considering the implementation of the Convention's criteria (see above), the diversity of the protected sites as well as the evolution of science itself. Additionally, it is mainly experts from these organizations that will undertake in situ fact-finding and monitoring missions ([50], p. 427), offer expertise and technical guidance to competent authorities and deliberate with local stakeholders in case further or corrective measures are needed ${ }^{44}$. Thus, the Advisory Bodies lend the system with scientific objectiveness, creating confidence between states parties and render the processes of nomination and monitoring less susceptible to political claims.

(c) introduction of a flexible system of soft-law rules that states cannot deviate from ([51], p. 1849): The Operational Guidelines for the implementation of the Convention are revised regularly ${ }^{45}$, keeping the Convention in pace with new challenges, whilst contributing to the uniformity among states parties' perception of (marine) World Heritage and conservation measures. The ad hoc technical support provided by the Convention's mechanism and the establishment of the World Heritage Marine Programme in 2005 [3] to support states with the nomination and conservation processes of marine properties constitute the main policy tools supporting uniformity and innovation in the World Heritage system. This is evident in the introduction of novel concepts of environmental protection such as the ecosystem-based approach ${ }^{46}$ and marine spatial planning ${ }^{47}$ ([17], p. 32) (the latter initially introduced as a management process for the conservation of a marine World Heritage site, Australia's Great Barrier Reef) [57,58].

(d) introduction (although tempered by the primacy of the host states) of a system of shared responsibility for the implementation of all the processes that would ensure the inscribed sites sustainability. According to the Convention primary responsibility for "the identification, protection, conservation, presentation and transmission to future generations of the cultural and natural heritage...situated in their territory," belongs to the host state. However, the Convention introduces the obligation of the international community to cooperate for the protection of world heritage by providing assistance to the host state once requested as well as by applying the due diligence principle [59] by abstaining from taking any measures that would cause damage to the heritage, situated in the territory of another state (Article 6). Additionally, while all decisions require the consent of the host state, the World Heritage Committee may "at any time, in case of urgent need," inscribe a property in the List of World Heritage in Danger (article 11, para. 4); in the same context, although not explicitly mentioned in the Convention ${ }^{48}$, the World Heritage Committee decides on the delisting of properties

Deliberations with local stakeholders as well as the managing authorities preceded the process of the consultation process with the competent authorities for the adoption of the additional measures in the case of the Belize Barrier Reef Reserve System in 2015 mentioned above [48].

45 From 1977 to 2015, the Operational Guidelines have been revised over 20 times [52].

46 There is no "universally agreed definition" of the eco-system based approach; there is, however, a common apprehension of its main components and processes, such as the conservation of the ecosystem structures, comprehensive and adaptive management, integration of regional seas concerns in marine management, adoption of participatory models of governance, and use of scientific and traditional knowledge [53,54].

47 Defined as " a [public] ([55], p. 18) process of analyzing and allocating parts of three-dimensional marine spaces to specific uses, to achieve ecological, economic and social objectives that are usually specified through the political process; the MSP process usually results in a comprehensive plan or vision for a marine region. MSP is an element of [ecosystem-based] ([55], pp. 7, 10) sea use management" ([56], p. 13)

48 The legal basis for delisting is article 11 para. 2 concerning the obligation of the World Heritage Committee to periodically update the World Heritage List. 
from the List [60]. Last but not least, the Convention establishes a mechanism of international cooperation and assistance, including both financial as well as operational support once requested.

\subsection{The Cultural Dimension}

According to the 2015 Operational Guidelines ([4], para. 119), "World Heritage properties may support a variety of ongoing and proposed uses that are ecologically and culturally sustainable and which may contribute to the quality of life of communities concerned." The Hanoi Statement has also stressed the need for synergies between the cultural and natural components of the World Heritage Convention, "especially in relation to [marine] ecosystems that have both outstanding concentrations of biodiversity and rich, traditional human cultures" [43].

In this context, cultural sustainability encompasses the tangible elements of human interaction with nature and the intangible elements that go hand in hand with the latter. These features apply mostly in the coastal or island landscapes or seascapes, a comparatively new category of cultural sites in the World Heritage List [61], representing "the combined works of man and nature" in the spirit of Article 1 of the Convention ${ }^{49}$, as "illustrative of the evolution of human society and settlement over time, under the influence of the physical constraints and/or opportunities presented by their natural environment" ([62], para. 36). The innovative approach of this category of protected sites relates to the combination of natural and cultural elements on the one hand and of tangible and intangible dimensions related to the human environment on the other. In the case of seascapes, this is interpreted as the inclusion of "the materiality of the biophysical world, the cultural lens through which we construct our world views and our lived experience of being on and in the sea" ([63], p. 21).

There are two marine mixed properties in the World Heritage List inscribed as cultural landscapes/seascapes: the volcanic archipelago of St Kilda in the United Kingdom and the Papahānaumokuākea in the Hawaiian archipelago in USA [3]. The added value of these nominations is that the cultural footprint on the environment, as a testimony of the sustainable use of the latter, is preserved, while, in the cases of living traditions, the associative element (spiritual values) is mainstreamed in the broader nature conservation schemes as a driver for sustainability of nature and culture. More specifically, tangible and intangible values associated to marine properties contribute to the development of sustainable economic activities, such as sustainable tourism or fisheries, and the use of traditional knowledge and practices in the protection of the marine environment. In this context, protection measures enjoy broader social legitimacy within local communities since they ensure social inclusiveness and equitable development [64].

Seascape inscriptions based mainly on cultural criteria may also enhance marine protection indirectly in cases where sites would not meet the natural criteria; in these cases, according to IUCN, marine sustainability would profit from "alternative means of [demonstrating] outstanding universal value" ([6], p. 7) through the extension of World Heritage standards in protection schemes to sites that are not considered exceptional.

\section{The World Heritage Convention and Its Impact on Non-Designated Sites}

Undoubtedly, the World Heritage Convention establishes a regime addressing the protection and conservation of marine sites of outstanding value falling within the jurisdiction of its Contracting States. However, other marine regions may benefit from its provisions but also from the dissemination of good

49 Article 1 defines cultural heritage as "monuments: architectural works, works of monumental sculpture and painting, elements or structures of an archaeological nature, inscriptions, cave dwellings and combinations of features, which are of outstanding universal value from the point of view of history, art or science; groups of buildings: groups of separate or connected buildings which, because of their architecture, their homogeneity or their place in the landscape, are of outstanding universal value from the point of view of history, art or science; sites: works of man or the combined works of nature and man, and areas including archaeological sites which are of outstanding universal value from the historical, aesthetic, ethnological or anthropological point of view." 
practice (e.g., maritime spatial planning mentioned above) and the contribution of the Convention to the construction of a global conscience concerning the management of ocean affairs.

\subsection{Marine Areas under National Jurisdiction}

In the case of marine areas falling under national jurisdiction that are not inscribed on the World Heritage List, we should distinguish two categories of marine sites: (a) areas that have been examined by the state party while fulfilling its obligation for identification of its natural heritage according to Article 3 of the Convention but were not included in the tentative list. Although the List addresses only marine sites of outstanding value, this does not undermine the national or regional significance of these properties. The latter may be defined during the process of natural heritage identification and become part of national or regional inventories. In certain cases, the examination of some of these sites during the identification process may receive international assistance "when preliminary investigations have shown that further inquiries should be justified" according to Article 13 para. 2; (b) areas that have been included in state parties' tentative lists, regardless the outcome of the process. The Convention defines a series of obligations to be assumed by states once they identify a property as natural (and/or cultural) heritage in Articles 5 and 6 (with the exception of Article 6 para. 2 provision) ${ }^{50}$. These obligations are identical to the ones applied in the case property has been inscribed on the World Heritage List. This is significant since the tentative list contains more sites than those listed extending in this way the scope of application of the Convention's principles and standards ([49], pp. 172-77).

\subsection{Synergies with the High Seas Regime}

The high seas fall out of the scope of the World Heritage Convention since the latter applies on marine areas under coastal states' jurisdiction. This is a significant impediment to the protection of the marine environment not only for ecosystem and biodiversity values in areas beyond national jurisdiction but also to the conservation of the intrinsic values of the marine World Heritage itself, taking into account the dependency of marine ecosystems through tidal circulation or the migration of species.

There is an ongoing debate on the potential contribution of the World Heritage Convention to the identification, protection and conservation of areas in the high seas initiated in line with the 2011 Global Strategy Evaluation [65] and the IUCN roadmap for addressing gaps in marine World Heritage protection [6]. According to the latter, the development of synergies with the system of the Convention on Biological Diversity and, more specifically, with the criteria for the identification of Ecologically or Biologically Significant Areas beyond the limits of national jurisdiction [66] seems to be one option. An alternative scenario would be the integration of the criteria of significant universal value in UNCLOS implementing agreements under the light of the recent developments concerning the elaboration of an "international legally binding instrument under the Convention on the conservation and sustainable use of marine biological diversity of areas beyond national jurisdiction" [67]. Last but not least, the incorporation of the World Heritage Convention's criteria and standards through the adoption of $a d$ hoc agreements following the example of the Pelagos Sanctuary ${ }^{51}$ could also be a possibility. However, the extension of World Heritage standards and criteria in the high seas constitutes a complex process due to the fragmentation of international governance structures as well as the reluctance of states to confine their rights in relation to the exercise of the freedom of the seas as stipulated in Part VII of UNCLOS.

50 In relation to the obligation of contracting parties to provide assistance for the "identification, protection, conservation and presentation of the cultural and natural heritage" inscribed on the World Heritage List or the List of World Heritage in Danger, following a request by the host state.

51 The Sanctuary for Mediterranean Marine Mammals was established by the Pelagos Agreement, signed by France, Italy and the Principality of Monaco. It includes marine areas falling within and beyond national jurisdiction representing a large ecosystem [68]. 


\section{Marine World Heritage and the Sustainable Development Goals: The Road Ahead}

The protection of marine sites within the broader context of natural heritage conservation was linked with Millennium Declaration Goal 7 on environmental sustainability and, more specifically, targets 7A on the integration of the principles of sustainable development into country policies and programs and the reversal of the loss of environmental resources and 7B on the reduction of biodiversity loss [69]. It should be mentioned that the World Heritage Convention does not make any reference to "sustainable development" in spite of the fact that the latter constitutes a conceptual component of the notion of "heritage" itself; in the context of mainstreaming World Heritage Objectives with concepts prevailing in the field of environmental protection and conservation, the term has been introduced for the first time in the Operational Guidelines of 1994 [62] in relation to the "sustainable use" of cultural landscapes to be followed by new additions to the 2008 Operational Guidelines ${ }^{52}$ revision [70]. The concept of sustainable development of marine World Heritage was linked to the conservation and transmission of the outstanding universal value of the properties on the one hand, and the development of the necessary processes in order to ensure sustainability on the other.

However, the Millennium Development Goals did not make any explicit reference to the marine environment. The latter was incorporated in the post-2015 sustainable development agenda of the United Nations with the introduction of Sustainable Development Goal 14 on the conservation and sustainable use of the oceans, seas and marine resources, with a fifteen-year horizon [71]. In view of the adoption of the Sustainable Development Goals, the Convention's system attempted to make a shift from the integration of sustainable development principles to the implementation of sustainable development techniques prioritizing capacity-building and their assessment through the development of quantitative and qualitative indicators [72] and the adoption of a clear policy on the integration of sustainable development into the processes of the World Heritage Convention " . . including standards on conservation and sustainable development, drawing on Rio+20 outcomes" [73]. The new policy was adopted in 2015. The main pillars of sustainable development mainstreaming in World Heritage conservation include environmental sustainability, inclusive social and economic development, and peace and security [74]. We are currently in the process of Operational Guidelines' revision. The marine World Heritage agenda is expected to undergo the necessary adjustments in order to meet the challenges of marine conservation under the strategic framework of the United Nations post-2015 agenda. What is novel, at least for marine properties, is the introduction of the dimension of peace and security in the conservation of their outstanding universal value. As far as the other dimensions are concerned, it seems that more emphasis will be given (a) to the involvement of local and indigenous communities in the World Heritage nomination, management and policy measures that may affect their territories, lands, resources and ways of life in line with the ecosystem-based approach; and (b) to the construction of more complex partnerships, where the "market mechanisms" will have to coexist with public policies ([74], p. 11), signaling a change of mentality in the way we perceive marine protected areas.

\section{Concluding Remarks}

The World Heritage Convention is one of the leading international instruments catering for the protection of the natural environment and the biological diversity of sites assigned with universal value. The inclusion of 'flagship' marine sites in the World Heritage List has introduced, in a systematic manner, a comprehensive model of conservation unfolding at various levels and encompassing different processes: from international to local; from standard setting procedures to management implementation and enhanced public involvement; and from intergovernmental practices to non-governmental participation in decision-making.

52 According to which "[t]he protection and conservation of the natural and cultural heritage are a significant contribution to sustainable development" ([70], para. 6). 
The integration of the marine dimension of world heritage in the Convention's system has resulted in the introduction of a number of novelties and good practices in the domain of marine environmental conservation and management, as well as concrete policy tools to be used in order to ensure sustainability, namely:

(a) The comprehensive approach vis à vis the marine space in terms of its ecological and social features as well as the cultural values (tangible and intangible) attached to the latter.

(b) The combination of environmental conservation to economic sustainability of local communities, national economies and marine management cost.

(c) The creation of a global consciousness on the value of these exceptional sites. The nomination of transboundary marine properties or the cooperation of marine World Heritage sites managers as well as the ongoing debate on the future of areas of universal value in the high seas reflect a shift from the conventional intergovernmental logic to a novel perception of marine environmental concerns.

(d) The ability of the Convention's system to promote a uniform approach on behalf of national authorities in terms of protection measures and management as well as to mainstream new trends and principles in environmental protection. The concept of outstanding universal value is constantly evolving, along with the natural criteria set by the Committee for its attribution to natural sites, and the horizontal criterion for integrity.

(e) The dissemination of sound and state of the art management techniques through capacity building assistance programs that enhance the ability of national and local authorities to cope with marine environmental conservation not confined in World Heritage sites but also in other marine areas.

(f) The creation of multilevel partnerships encompassing the adoption of participatory models of decision-making through the involvement of local stakeholders in the process of World Heritage conservation, as well as the provision of expertise from international advisory bodies.

However, the nomination of marine sites in the World Heritage List faces significant challenges that may often transcend the capacity of the system to cope with. The first relates to the fragmentation of the international maritime governance system. In spite of the fact that there is a plethora of international instruments relating to different aspects of maritime affairs, there are significant gaps in international regulation, especially concerning the high seas regime. Additionally, this institutional fragmentation confines the ability of effective management of global challenges, such as the impact of climate change, transboundary pollution or accidents at sea. Inter-institutional synergies at the international level have not yet been adequately developed, although it seems that the World Heritage approach has attempted to take into consideration the benefits from coordination with different (not always) environmental regimes.

Another very important challenge relates to the fact that marine conservation and management may be easily undermined due to maritime claims and pending boundary disputes that usually hinder the designation of World Heritage marine sites in order to avoid tensions. In spite of the fact that the Convention addresses these situations ${ }^{53}$, states hesitate to open Pandora's box by submitting marine nominations in disputed areas. The limited nominations in the Mediterranean or the South China Seas ([75], pp. 92-93) constitute illustrative examples of states' reluctance to submit marine properties' nominations in order to avoid accentuating existing disputes or creating new ones.

53 According to Article 11 para. 3, "[t]he inclusion of a property in the World Heritage List requires the consent of the state concerned. The inclusion of a property situated in the territory, sovereignty or jurisdiction over which is claimed by more than one state shall in no way prejudice the rights of the parties to the dispute." 
Last but not least, marine heritage conservation constitutes an expensive venture. The allocation of funds from national budgets does not seem to be an option for most of the host states, while the Convention's system has limited capacity for financial support. International and regional financial mechanisms as well as donations from the private sector seem to be the only realistic scenario, which also requires the development of mechanisms and skills on behalf of the competent authorities in order to be successful. In spite of the fact that capacity-building is one of the priorities in World Heritage management, the prioritization of the issues related to the complementarity of financial resources and the financial aspects of marine properties management could address, at least to a certain degree, the challenges of financial sustainability of marine heritage protection schemes.

Acknowledgments: I would like to cordially thank the anonymous reviewers for their comments and input, the editors for their kind support and Androklis Kevrekidis for his assistance in delivering this paper.

Conflicts of Interest: The author declares no conflict of interest.

\section{References and Notes}

1. For a commentary of Article 2 see Catherine Redgwell. Article 2. "Definition of Natural Heritage." In The 1972 World Heritage Convention. A Commentary. Edited by Francesco Francioni and Federico Lenzerini. Oxford: Oxford University Press, 2008, pp. 63-84.

2. World Heritage Committee. "Operational Guidelines for the Implementation of the World Heritage Convention (CC-17/CONF.OOl/8)." 20 October 1977. Available online: http://whc.unesco.org/archive/ opguide77b.pdf (accessed on 27 October 2015).

3. UNESCO. "World Heritage Marine Programme." Available online: http://whc.unesco.org/en/marineprogramme/ (accessed on 27 October 2015).

4. World Heritage Committee. "Operational Guidelines for the Implementation of the World Heritage Convention (WHC.15/01)." 8 July 2015. Available online: http:/ /www.unesco.at/kultur/basisdokumente/ OpGuidelines.pdf (accessed on 27 October 2015).

5. Annie Hillary, Marjaana Kokkonen, and Lisa Max, eds. Proceedings of the World Heritage Marine Biodiversity Workshop. Paris: UNESCO, 2003.

6. Ameer Abdulah, David Obura, Bastian Bertzky, and Yichuan Shi. Marine Natural Heritage and the World Heritage List. Interpretation of World Heritage Criteria in Marine Systems, Analysis of Biogeographic Representation of Sites, and a Roadmap for Addressing Gaps. Paris: UNESCO, 2013.

7. World Commission on Environment and Development (WCED). Our Common Future. Oxford: Oxford University Press, 1987.

8. Mariola Grzebyk, and Malgorzata Stec. "Sustainable Development in EU Countries: Concepts and Rating of Levels of Development." Sustainable Development 23 (2015): 110-23. [CrossRef]

9. Bill Hopwood, Mary Mellor, and Geoff O’Brien. "Sustainable Development: Mapping Different Approaches." Sustainable Development 13 (2005): 38-52. [CrossRef]

10. Sharachchandra M. Lélé. "Sustainable Development: A Critical Review." World Development 19 (1991): 607-21. [CrossRef]

11. Dinorah Frutos-Beneze. "Enviornmental Sustainability in the CAFTA-DR Region: Impact of the Treaty's Environmental Provisions on Country and Multinational Firm Level Sustainability." In Beyond the UN Global Compact: Institutions and Regulations. Edited by Liam Leonard and Maria-Alejandra Gonzalez Perez. Bingley: Emerald Group Publishing Limited, 2015, pp. 147-68.

12. Marco Keiner. "Re-emphasizing Sustainable Development-The Concept of 'Evolutionability'. On Living Chances, Equity, and Good Heritage." Environment, Development and Sustainability 6 (2004): 379-92. [CrossRef]

13. Stephen Morse. "Developing Sustainability Indicators and Indices." Sustainable Development 23 (2015): 84-95. [CrossRef]

14. Herman E. Daly. "Toward some operational principles of sustainable development." Ecological Economics 2 (1990): 1-6. [CrossRef] 
15. UNESCO. Preparing World Heritage Nominations. Paris: UNESCO, 2011.

16. Nora Mitchell. Study on the Application of Criterion VII. Considering Superlative Natural Phenomena and Exceptional Natural Beauty within the World Heritage Convention. Gland: IUCN, 2013.

17. Charles Ehler, and Fanny Douvere. Navigating the Future of Marine World Heritage. Results from the first World Heritage Marine Site Managers. Paris: UNESCO, 2011, Available online: http://whc.unesco.org/ documents/publi_wh_papers_28_en.pdf (accessed on 30 October 2015).

18. International Law Commission. "Draft principles on the allocation of loss in the case of transboundary harm arising out of hazardous activities, with commentaries." In Yearbook of the International Law Commission. New York: United Nations Publications, 2006, vol. 2, pp. 110-82.

19. Fanny Douvere. World Heritage Marine Sites. Managing Effectively the World's Most Iconic Marine Protected Areas. Best Practice Guide. Paris: UNESCO, 2015.

20. UNESCO. "The Strategic Action Plan and Vision to guide the implementation of the World Heritage Convention over the decade 2012-2022." Paper presented at Resolution 18 GA 11 of the 18th session of the General Assembly of States Parties, Saint Petersburg, Russian Federation, 24 June-6 July 2012. Available online: http:/ / whc.unesco.org/archive/2012/whc12-36com-12A-en.pdf (accessed on 1 November 2015).

21. Giovanni Boccardi. "World Heritage and Sustainable Development on the 40th Anniversary of the Convention." In The Protection of Archaeological Heritage in Times of Economic Crisis. Edited by Elena Korka. Newcastle upon Tyne: Cambridge Scholars Publishing, 2014, pp. 10-17.

22. World Heritage Committee. "World Heritage Convention and Sustainable Development (Decision: 36COM5C)." 11 May 2012. Available online: http:// whc.unesco.org/archive/2012/whc12-36com-5C-en.pdf (accessed on 1 November 2015).

23. Elena Osipova, Lisette Wilson, Ralph Blaney, Yichuan Shi, Max Fancourt, Miranda Strubel, Tania Salvaterra, Claire Brown, and Bas Verschuuren. The Benefits of Natural World Heritage: Identifying and Assessing Ecosystem Services and Benefits provided by the World's most Iconic Natural Places. Gland: IUCN, 2014.

24. PROWAD. Protect \& Prosper. "Sustainable Tourism in the Wadden Sea." Available online: http://www. waddensea-secretariat.org/management/projects/prowad (accessed on 2 November 2015).

25. Nicolas Pascal. "Ecosystèmes coralliens de Nouvelle-Calédonie. Valeur économique des services éco systémiques." 2010. Available online: http://www.oeil.nc/cdrn/index.php/resource/bibliographie/view/45 (accessed on 2 November 2015).

26. Federico Lenzerini. "Articles 15-16. World Heritage Fund." In The 1972 World Heritage Convention. A Commentary. Edited by Francesco Francioni and Federico Lenzerini. Oxford: Oxford University Press, 2008, pp. 269-87.

27. Anne Lemaistre, and Federico Lenzerini. "Articles 19-26. International Assistance." In The 1972 World Heritage Convention. A Commentary. Edited by Francesco Francioni and Federico Lenzerini. Oxford: Oxford University Press, 2008, pp. 305-24.

28. UNESCO. “International Assistance-Statistics.” Available online: http://whc.unesco.org/en/intassistance/ action=stats (accessed on 15 November 2015).

29. Global Environmental Facility. "The Global Environmental Facility Dynamic Parterships. Real Solutions." Available online: http:/ / www.un.org/events/wssd/exhibit/GEF.pdf (accessed on 15 November 2015).

30. United Nations. "Report of the United Nations Conference on the Human Environment (A/CONF.48/ 14/Rev.1)." 1972. Available online: http://www.un-documents.net/aconf48-14r1.pdf (accessed on 28 October 2015).

31. Antonio Augusto Cancado Trindade. "International Law for Humankind towards a new Jus Gentium." Recueil Des Cours 316 (2005): 9-439.

32. Kemal Balsar. The Concept of Common Heritage of Mankind in International Law. Dordrecht: Martinus Nijhoff, 1998.

33. Tara Smith. "Creating a Framework for the Prosecution of Environmental Crimes in International Criminal Law." In The Ashgate Research Companion to International Criminal Law: Critical Perspectives. Edited by William A. Schabas Yvonne McDermott, Niamh Hayes and Maria Varaki. Surrey and Burlington: Ashgate Publishers, 2012, pp. 45-62.

34. Micaella Fruli. "The Criminalization of Offences against Cultural Heritage in Times of Armed Conflict: The Quest for Consistency." European Journal of International Law 22 (2011): 203-17. [CrossRef] 
35. Prosecutor v. Miodrag Jokic, ICTY Case No. IT-01-42/1-S, Judgment of 18 March 2004.

36. Prosecutor v. Ahmad Al Faqi Al Mahdi, ICC-01/12-01/15.

37. René Jean Dupuy, and Daniel Vignes, eds. A Handbook on the New Law of the Sea. Dordrecht: Martinus Nijhoff, 1991, vol. 1.

38. John Noyes. “The Common Heritage of Mankind: Past, Present, and Future.” Denver Journal of International Law \& Policy 40 (2011): 447-71.

39. Ameer Abdulla, David Obura, Bastian Bertzky, and Yichaun Shi. "Marine World Heritage: Creating a Globally more Balanced and Representative List." Aquatic Conservation: Marine and Freshwater Ecosystems 24 (2014): 59-74. [CrossRef]

40. Edith Brown Weiss. "Intergenerational equity: A legal framework for global environmental change." In Environmental Change and International Law: New Challenges and Dimensions. Edited by Edith Brown Weiss. Tokyo: United Nations University Press, 1992.

41. Nico Schrijver. "Le rôle de l'UNESCO dans la formation et l'application du droit international: évaluation." In L'action normative à l'UNESCO. Vol. I. Elaboration de règles internationales sur l'éducation, la science et la culture. Edited by Abdulqawi A. Yusuf. Paris and Leiden: Editions UNESCO, Martinus Nijhoff Publishers, 2007, pp. 385-405.

42. Guido Carducci. "Articles 4-7." In The 1972 World Heritage Convention. A Commentary. Edited by Francesco Francioni and Federico Lenzerini. Oxford: Oxford University Press, 2008, pp. 103-45.

43. World Heritage Committee. "Hanoi Statement." Available online: http://whc.unesco.org/document/10053 (accessed on 18 January 2016).

44. Peter H. Sand. "The Concept of Public Trusteeship in the Transboundary Governance of Biodiversity." In Transboundary Governance of Biodiversity. Edited by Louis Kotzé and Tuilo Marauhn. Leiden and Boston: Brill Nihjoff, 2014, pp. 34-63.

45. Evangelos Raftopoulos. "The Barcelona Convention as an International Trustee Regime: The Public Participation Aspect." MEPIELAN e-bulletin, 2012. Available online: http:/ /www.mepielan-ebulletin.gr/ default.aspx?pid=18\&CategoryId=4\&ArticleId=120\&Article=The-Barcelona-Convention-System-as-anInternational-Trust-Regime-The-Public-Participation-Aspect (accessed on 12 November 2012).

46. World Heritage Committee. “Belize Barrier Reef System (Belize) (N 764) (Decision: 33 COM 7B.33)." 2009. Available online: http://whc.unesco.org/en/decisions/1825 (accessed on 15 November 2015).

47. UNESCO. “Belize Barrier Reef Reserve System." Available online: http://whc.unesco.org/en/list/764/ documents (accessed on 5 November 2015).

48. UNESCO. “Belize Barrier Reef Reserve System. State of Conservation." Available online: http://whc. unesco.org/en/soc/3189 (accessed on 5 November 2015).

49. Edward J. Goodwin. International Environmental Law and the Conservation of Coral Reefs. London and New York: Routledge, 2011.

50. Alexander Gillespie. Conservation, Biodiversity and International Law. Cheltenham and Northampton: Edward Elgar, 2011.

51. Diana Zacharias. "The UNESCO Regime for the Protection of World Heritage as Prototype of an Autonomy-Gaining International Institution." German Law Review 9 (2006): 1833-64.

52. UNESCO. "The Operational Guidelines for the Implementation of the World Heritage Convention." Available online: http://whc.unesco.org/en/guidelines/ (accessed on 3 November 2015).

53. United Nations General Assembly. "Report on the Work of the United Nations Open-Ended Informal Consultative Process on Oceans and the Law of the Sea at its Seventh Meeting (A/61/156)." 17 July 2006. Available online: http:/ / daccess-dds-ny.un.org/doc/UNDOC/GEN/N06/432/90/PDF/N0643290.pdf? OpenElement (accessed on 18 November 2015).

54. Stelios Katsanevakis, Vanessa Stelzenmüller, Andy South, Thomas Kirk Sørensen, Peter J.S. Jones, Sandy Kerr, Fabio Badalamenti, Christos Anagnostou, Patricia Breenc, Guillem Chusth, and et al. "Ecosystem-based marine spatial management: Review of concepts, policies, tools and critical issues." Ocean $\mathcal{E}$ Coastal Management 54 (2011): 807-20. [CrossRef] 
55. Charles Ehler, and Fanny Douvere. Marine Spatial Planning: A Step-By-Step Approach toward Ecosystem-Based Management. Intergovernmental Oceanographic Commission and Man and the Biosphere Programme. IOC Manual and Guides 53, ICAM Dossier 6; Paris: UNESCO, 2009.

56. Charles Ehler, and Fanny Douvere. Visions for a Sea Change. Report of the First International Workshop on Marine Spatial Planning. Intergovernmental Oceanographic Commission and Man and the Biosphere Programme. IOC Manual and Guides 46, ICAM Dossier 3; Paris: UNESCO, 2007.

57. Jon Day. "The Need and Practice of Monitoring, Evaluating and Adapting Marine Planning and Management-Lessons from the Great Barrier Reef." Marine Policy 32 (2008): 823-31. [CrossRef]

58. Fanny Douvere. "The Importance of Marine Spatial Planning in Achieving Eco-system Based Sea Use Management." Marine Policy 32 (2008): 762-71. [CrossRef]

59. Timo Koivurova. "Due Diligence." In Max Planck Encyclopedia of Public International Law. Edited by Rüdiger Wolfrum. Oxford: Oxford University Press, 2011.

60. Gionata P. Buzzini, and Luigi Condorelli. "Article 11: List of World Heritage in Danger and Deletion of a Property from the World Heritage List." In The 1972 World Heritage Convention. A Commentary. Edited by Francesco Francioni and Federico Lenzerini. Oxford: Oxford University Press, 2008, pp. 175-99.

61. Bernd Von Droste, Harald Plachter, and Mechtild Rössler, eds. Cultural Landscapes of Universal Value. Components of a Global Strategy. Jena: Fischer Verlag, 1995.

62. World Heritage Committee. “Operational Guidelines for the Implementation of the World Heritage Convention (WHC/2/Revised)." February 1994. Available online: http://whc.unesco.org/archive/ opguide94.pdf (accessed on 12 November 2015).

63. Mike Brown. "Seascapes." In Seascapes: Shaped by the Sea. Embodied Narratives and Fluid Geography. Edited by Mike Brown and Barbara Humberstone. Surrey: Ashgate, 2015, pp. 13-26.

64. UNESCO. “UN System Task Team on the post-2015 Development Agenda. Culture: A driver and an enabler of sustainable development. Thematic Think Piece." May 2012. Available online: http://en.unesco.org/ post2015/sites/post2015/files/Think\%20Piece\%20Culture.pdf (accessed on 15 November 2015).

65. World Heritage Committee. "Evaluation of the Global Strategy and the PACT Initiative (WHC-11/35. COM/9A)." 27 May 2011. Available online: http://whc.unesco.org/archive/2011/whc11-35com-9Ae1.pdf (accessed on 15 November 2015).

66. Convention on Biological Diversity. "Marine and coastal biodiversity (COP 9 Decision IX/20)." May 2008. Available online: https:/ / www.cbd.int/decision/cop/?id=11663 (accessed on 18 November 2015).

67. United Nations General Assembly. “Development of an international legally—Binding instrument under the United Nations Convention on the Law of the Sea on the conservation and sustainable use of marine biological diversity of areas beyond national jurisdiction (A/69/L.65, 11)." May 2015. Available online: http://www.un.org/en/ga/search/view_doc.asp?symbol=A/RES/69/292 (accessed on 15 November 2015).

68. Pelagos Sanctuary. "Presentation of the Pelagos Sanctuary." Available online: http://www.sanctuairepelagos.org/en/home/66-anglais/uncategorised/254-presentation-of-the-pelagos-sanctuary (accessed on 17 January 2016).

69. United Nations. "Millennium Goals." Available online: http://www.un.org/millenniumgoals/ (accessed on 15 November 2015).

70. World Heritage Committee. "Operational Guidelines for the Implementation of the World Heritage Convention (WHC/08/01)." January 2008. Available online: http://whc.unesco.org/archive/opguide08en.pdf (accessed on 19 November 2015).

71. United Nations. "Sustainable Development Goals." Available online: https://sustainabledevelopment. un.org/?menu=1300 (accessed on 15 November 2015).

72. World Heritage Centre. “Toyama Proposal on Heritage Sustainable Development." 5 November 2012. Available online: http://whc.unesco.org/en/sustainabledevelopment/ (accessed on 15 November 2015).

73. Giovanni Boccardi, and Lindsay Scott. "Developing a proposal for the integration of a sustainable development perspective within the processes of the World Heritage Convention. Working Document." April 2014. Available online: http://whc.unesco.org/en/sustainabledevelopment/ (accessed on 15 November 2015). 
74. World Heritage Committee. "Item 5 of the Provisional Agenda: Reports of the World Heritage Centre and the Advisory Bodies. World Heritage and Sustainable Development (WHC-15/39.COM/5D)." 15 May 2015. Available online: http:/ / whc.unesco.org/archive/2015/whc15-39com-5D-en.pdf (accessed on 18 January 2016).

75. Aldo Chircop. "Regional Cooperation in Marine Environmental Protection in the South China Sea: A Reflection on New Directions for Marine Conservation." In Maritime Issues in the South China Sea. Troubled Waters or a Sea of Opportunity? Edited by Nien-Tsu Alfred Hu and Ted L. Mc Dorman. London and New York: Routledge, 2013, pp. 87-109.

(C) 2016 by the author; licensee MDPI, Basel, Switzerland. This article is an open access article distributed under the terms and conditions of the Creative Commons by Attribution (CC-BY) license (http://creativecommons.org/licenses/by/4.0/). 